\title{
An ecohydrological sketch of climate change impacts on water and natural ecosystems for the Netherlands: bridging the gap between science and society
}

\author{
J. P. M. Witte ${ }^{1,2}$, J. Runhaar ${ }^{1}$, R. van Ek ${ }^{3}$, D. C. J. van der Hoek ${ }^{4}$, R. P. Bartholomeus ${ }^{1}$, O. Batelaan ${ }^{5,6}$, P. M. van \\ Bodegom $^{2}$, M. J. Wassen ${ }^{7}$, and S. E. A. T. M. van der Zee ${ }^{8}$ \\ ${ }^{1}$ KWR Watercycle Research Institute, P.O. Box 1072, 3430 BB Nieuwegein, The Netherlands \\ ${ }^{2}$ VU University Amsterdam, Department of Ecological Science, De Boelelaan 1085, 1081 HV Amsterdam, The Netherlands \\ ${ }^{3}$ Deltares, P.O. Box 85467, 3508 AL Utrecht, The Netherlands \\ ${ }^{4}$ PBL Netherlands Environmental Assessment Agency, P.O. Box 303, 3720 AH Bilthoven, The Netherlands \\ ${ }^{5}$ Dept. of Hydrology and Hydraulic Engineering, Vrije Universiteit Brussel, Pleinlaan 2, 1050 Brussels, Belgium \\ ${ }^{6}$ School of the Environment, Flinders University, GP.O. Box 2100, Adelaide, South Australia 5001, Australia \\ ${ }^{7}$ Environmental Sciences, Faculty of Geosciences, Copernicus Institute of Sustainable Development, Utrecht University, \\ Heidelberglaan 2, 3584 CS Utrecht, The Netherlands \\ ${ }^{8}$ Wageningen UR, Environmental sciences, Soil Physics, Ecohydrology and Groundwater Management Group, P.O. Box 47, \\ 6700 AA Wageningen, The Netherlands
}

Correspondence to: J. P. M. Witte (flip.witte@kwrwater.nl)

Received: 25 April 2012 - Published in Hydrol. Earth Syst. Sci. Discuss.: 23 May 2012

Revised: 1 October 2012 - Accepted: 3 October 2012 - Published: 1 November 2012

\begin{abstract}
For policy making and spatial planning, information is needed about the impacts of climate change on natural ecosystems. To provide this information, commonly hydrological and ecological models are used. We give arguments for our assessment that modelling only is insufficient for determining the impacts of climate changes on natural ecosystems at regional scales. Instead, we proposed a combination of hydrological simulations, a literature review and processknowledge on climate-hydrology-vegetation interactions, to compile a sketch map that indicates climate change effects on a number of ecosystems in the Netherlands. Soon after a first version of our sketch map was published by a Dutch professional journal, copies appeared in policy documents, and also in a commercial and popular atlas of the Netherlands. Moreover, the map led to a question in the Dutch parliament about the sustainability of bog reserves under the future climate. Apparently, there was an urgent need for the information provided by the map.

The map shows that climate change will presumably have the largest influence on ecosystems in the Netherlands that depend on precipitation as the major water source, like heath-
\end{abstract}

lands, dry grasslands, rain-fed moorland pools and raised bogs. Also highly susceptible are fens in reserves surrounded by deeply drained polders, because such fens depend on the inlet of surface water, of which quality is likely to deteriorate upon climate change. While the map is indicative for directions of change, in view of the uncertainties of our study, no conclusions should be drawn that may have far-reaching consequences, such as giving up certain nature targets that might no longer be feasible in the future climate. Instead, we advise to anticipate the potential threats from climate change by taking a number of adaptation measures that enhance the robustness of nature reserves.

To improve climate change projections on hydrology and ecosystems, future research should especially focus on feedbacks of vegetation on the water balance, on processes that directly influence plant performance and on the ecological effects of weather extremes. 


\section{Introduction}

Both observations and model simulations indicate that the climate of our Earth is changing at an unprecedented pace (Dai, 2011; Karl et al., 1995; Solomon et al., 2007). It is foreseen that not only temperature will rise, but also that more prolonged dry periods will alternate with more intensive rainfall events, both within and between years. This will change, among others, soil moisture dynamics (Easterling et al., 2000; Fay et al., 2008; Knapp et al., 2008b; Porporato et al., 2004; Weltzin et al., 2003). Soil moisture is the most important environmental filter of local terrestrial plant species composition, as it determines the availability of both oxygen and water to plant roots and, with that, indirectly other habitat factors that are essential for plant growth, such as soil acidity and nutrient availability (Bartholomeus et al., 2011a; Easterling et al., 2000; Knapp et al., 2008b; Levine et al., 2008; Porporato et al., 2004; Weltzin et al., 2003; Witte et al., 2007).

In view of the projected change in climate and hydrology, it is questionable whether target ecosystems for nature preservation may still be attained under a future climate. This is important, since most of such targets are legally enforced, e.g. by the European Habitat Directive, by the Water Framework Directive and by national legislations of several countries. For a timely response to climate change, as well as to avoid measures that may be ineffective, policy makers and spatial planners require information about the feasibility of nature targets under a future climate. It is inevitable that models are used for this purpose, because the empirical basis for climate change effects in the recent past, across transects that cover different climate zones, is too small. However, it is debatable whether current models are properly equipped for assessing climate change effects on nature targets.

\subsection{The appropriateness of models to evaluate climate change impacts}

Impacts of the water regime on natural vegetation in the Netherlands have been assessed by vegetation models on the basis of results obtained with transient hydrological modelling (Olde Venterink and Wassen, 1997; Witte et al., 2008b). Developments in both types of models and in their combination have been tremendous during the past two decades.

Transient hydrological models are especially needed in low lying areas such as the Netherlands, where groundwater levels in large parts of the country are shallow so that capillary flow from the groundwater table to the rooting zone is an important source of water supply to crops and natural vegetation. A major limitation to the combined modelling of surface water, groundwater and the water-unsaturated zone is that few integrated models are available that rigorously link these zones. A well-known example is GeoHydroSphere (Sudicky et al., 2008). When they are used, e.g. for shallow ground- water wetlands, they are very computationally demanding (Frei et al., 2010). Alternatively, so-called minimalist modelling according to the new ecohydrological framework that follows a systems analysis approach (Rodriguez-Iturbe and Porporato, 2004) has predominantly focussed on semi-arid situations. Approaches that account for capillary replenishment of root zone water are limited (Vervoort and Van der Zee, 2008). At this moment, such approaches are conceptual rather than directly applicable for the present purpose.

Hence, in practice the groundwater is typically modelled using codes such as Modflow (Harbaugh et al., 2000), for local and small catchment scales, or even for the whole of the Netherlands (comprising $35000 \mathrm{~km}^{2}$ ). Since Modflow is a saturated zone flow model, the top system has either to be simulated with a separate model that explicitly addresses the vadose zone (e.g. SWAP; Van Dam et al., 2008), or it has to be adequately mimicked in the Modflow boundary conditions. This is feasible if vegetation is conceptualized as a layer with fixed characteristics that partitions precipitation into intercepted rain water $\left(E_{\mathrm{i}}\right)$, evaporation from the soil $\left(E_{\mathrm{s}}\right)$ and water uptake from the soil by roots (transpiration, $T$ ). Errors in the simulated actual evapotranspiration (ET) can be considerable (e.g. Liu and Yang, 2010; Moore and Heilman, 2011; Zhang et al., 2010) but are usually obscured because modelling is not validated on ET. Though the availability of measured actual ET, e.g. from the global network of micrometeorological tower sites FLUXNET and from satellite algorithms like SEBAL (Bastiaanssen et al., 1998), increases rapidly, such data are only exceptionally used to calibrate a hydrological model (but see e.g. Schuurmans et al., 2003). Instead, it is common practice to calibrate hydrological models on measured groundwater levels and, when available, on measured surface water discharges, i.e. by adjusting the soil physical properties of the subsoil, such as the transmissivity of the underlying aquifers. Whereas in this way a good description of observed groundwater levels may be achieved, there is no reason why this should lead to accuracy with regard to the different water fluxes. Moreover, it is doubtful whether such a model is suitable for climate projections since it is not calibrated on the entity ET that, together with precipitation $(P)$ and surface runoff, actually determines groundwater recharge and thus drives the groundwater system.

Even more constraints relate to the application of hydrological model in climate projections. In most regional hydrological models, vegetation is not explicitly represented, and conceptual parameterizations are used to find actual ET. Actual ET is estimated by scaling potential ET using empirical functions of soil moisture and/or vegetation (Arora, 2002). For instance, potential ET is usually derived from a reference ET, provided by a meteorological institute, via an empirical crop or vegetation-type dependent factor. This approach (sensu Allen et al., 2005; Feddes, 1987) may be preferred for model simplicity, but such factors can only be applied under the climate conditions for which they were 
determined, especially since they implicitly include interception, a term that is highly dependent on the precipitation regime (which is likely to change). In addition, hydrological models often do not account for the fact that plants may reduce their future transpiration rate because their necessary consumption of carbon through their stomata is fulfilled more easily at enhanced atmospheric $\mathrm{CO}_{2}$-levels (De Boer et al., 2011; Kruijt et al., 2008). Finally, in practice current transient models do not account for the fact that vegetation may respond to increased drought by changes in vegetation cover and in rooting depth (Knapp et al., 2008b; Moore and Heilman, 2011; Porporato et al., 2001; Wegehenkel, 2009). In the Netherlands, this adaptation of vegetation to climate change can especially be expected on elevated sandy soils with deep groundwater tables, such as Pleistocene hills and coastal dunes. For those areas it is predicted that the fraction of bare soil and non-rooting species (lichens and mosses) in the vegetation will increase when summers become drier (Kamps et al., 2008; Wegehenkel, 2009; Witte et al., 2008a). This could increase future groundwater recharge, as actual ET decreases with decreasing vascular plant cover.

The importance of explicitly considering vegetation in hydrological models and the explicit distinction of soil evaporation, transpiration and interception is increasingly recognized (Brooks et al., 2011; Jackson et al., 2009; Liu, 2009), and there are ongoing efforts to partition measured actual ET into evaporation and $T$ (e.g. Wang et al., 2010). Nevertheless, only few studies exist that consider the vegetation as a dynamic component and that attempt to account for the dynamic interactions between hydrology and vegetation (e.g. Brolsma et al., 2010; Gerten et al., 2004; Wigmosta et al., 2002). However, because such models are very data and computationally demanding, they are not yet applicable for climate projections on a regional scale, certainly not in an area with shallow groundwater levels, such as the Netherlands.

In addition to hydrological models, also the application of vegetation models to evaluate the impact of climate projections on nature targets is not without complications. To predict changes in vegetation distribution due to global change, various models have been developed, each with its own approach, scale and timeline, and thus also each with its own strengths and limitations (Douma et al., 2012b). Of these models, habitat distribution models (HDMs) play an important role (Guisan and Zimmermann, 2000). Current HDMs, however, are likely inapplicable under changing climatic conditions for at least three reasons. First, they use relationships based on measurements for the current climate, assuming steady state or pseudo steady-state conditions (Guisan and Thuiller, 2005). Climate change is irreconcilable with steady state, and various studies have indicated that upon changing conditions other processes may become important, including vegetation adaptation, shifts in feedback mechanisms and switches in the type of resource limitation (light, water, nitrogen, phosphorus) (Van Bodegom et al., 2012). Second, the applied relationships between environmental factors and vegetation characteristics are often highly correlative and do not include climate variables like temperature, which impedes application to other climatic conditions (Bartholomeus et al., 2011b; Botkin et al., 2007; Guisan and Thuiller, 2005; Pearson and Dawson, 2003). Third, they do not account for no-analogue combinations of environmental conditions (Bartholomeus et al., 2011a).

Based on empirical work on competition for resources between species, also a few mechanistic competitionsuccession models have been built that can be used for climate projections (for the Netherlands: Van Oene et al., 1999; Van Oene and Berendse, 2001). A drawback of these models is that the inclusion of more processes requires a higher number of input parameters, which usually comes at the cost of the model accuracy and applicability (Baird, 1999; Douma, 2011; Guisan and Zimmermann, 2000). For this reason, mechanistic models have only been applied to a limited number of well-studied species and ecosystems (Morin and Lechowicz, 2008).

\subsection{An alternative: the ecohydrological sketch map}

We conclude that neither hydrological nor vegetation models are currently suited to reliably assess the effects of climate change on natural vegetation on landscape scales varying from small catchments to the whole of the Netherlands. Therefore, we adopted an alternative approach, in which we combined model results with a literature survey, process knowledge and the consultation of experts, to compile an approximate sketch map that indicates how a number of characteristic ecosystems will likely be affected by changes in the water regime that are induced by climate change. For illustration, and because of the wealth of information for the Dutch delta region, we focussed on the Netherlands. The Dutch delta and its transition to the upstream higher regions is one of the important geohydrological reference cases, comparable to other such EU regions (e.g. Rhone, Po, Danube's and Ebro's deltas and estuaries), which are of similar ecological importance. Moreover, we considered possible ecohydrological effects of two climate scenarios: a relatively dry one and a relatively wet one.

The purpose of the map was not only to stimulate and guide policy makers, spatial planners, natural resource managers and water managers in their thinking about climate change effects, but to elicit comments from the scientific community as well. The aim of this paper is to present (a) the decisions taken to compile the map, (b) the sketch map and the ecohydrological implications and (c) discuss how it was perceived by the general public. 
(a)

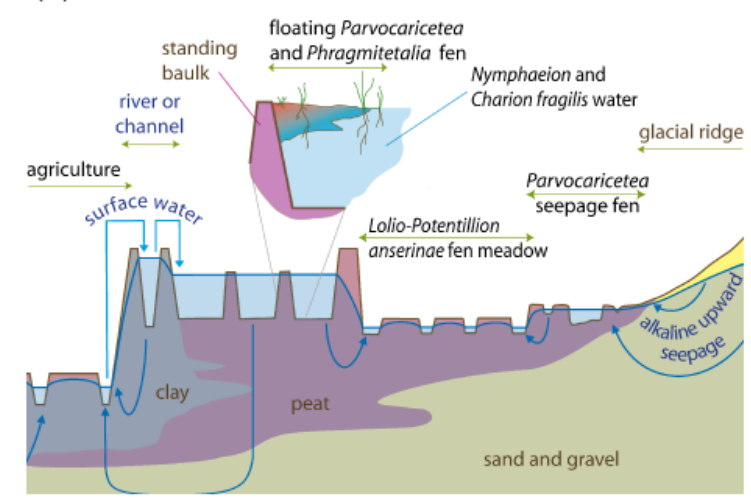

(b)

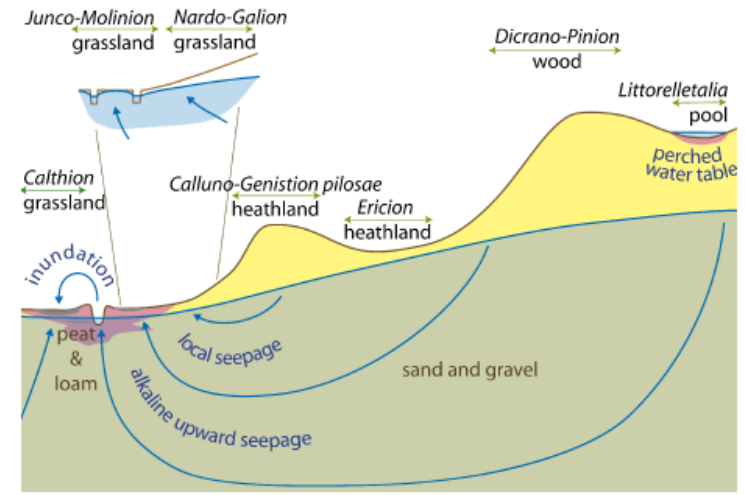

Fig. 1. Schematized ecohydrological cross sections, measuring ca. $10 \mathrm{~km}$ in width and $10 \mathrm{~m}$ in height, of (a) a fen landscape and (b) a coversand landscape. These landscapes occur in the "low" and "high" part of the Netherlands, respectively. Some characteristic vegetation types at the level of alliances and orders are indicated in italics (nomenclature according to Schaminée et al., 1995).

\section{Material and methods}

\subsection{Hydrological characterization of the Netherlands}

The Netherlands is a small and flat country with a temperate sea climate that has small spatial differences in meteorological conditions. The mean summer and winter temperatures are $16^{\circ} \mathrm{C}$ and $3{ }^{\circ} \mathrm{C}$, respectively; the mean yearly precipitation is $770 \mathrm{~mm}$ and the mean yearly Makkink (1957) reference evapotranspiration is $563 \mathrm{~mm}$. From a hydrological viewpoint the country can be divided into (1) a "high part" where drainage is mostly by gravity, found in the coastal dunes in the west (elevation up to 80 ma.m.s.l.) and the Pleistocene cover sand landscape and ice-pushed ridges in the middle, east and south (elevation up to $150 \mathrm{~m}$ a.m.s.l.), and (2) the clayey and peaty "low part" formed during the Holocene transgressions in the west and north of the Netherlands (elevation -5 to $+5 \mathrm{~m}$ a.m.s.l.), consisting of polders where the surface water regime is artificially controlled by the inlet of surface water in times of water shortage and by pumping out water in case of water excess. Figure 1 shows cross sections of two characteristic landscapes: a stream valley in the high part and a fen area in the low part.

\subsection{Climate scenarios}

In 2006, based on general circulation model simulations published in the Fourth Assessment Report of the IPCC (Solomon et al., 2007), the Royal Netherlands Meteorological Institute (KNMI) issued four climate scenarios which include changes in temperature, $P$ and reference ET (Van den Hurk et al., 2006). Here, we focused on the two warmest scenarios for our sketch map: the $\mathrm{W}$ and the $\mathrm{W}+$ scenarios. Both scenarios are related to the IPCC A2 and A1B scenarios and comprise a $+2{ }^{\circ} \mathrm{C}$ global temperature increase. On an annual basis, the $\mathrm{W}$ scenario has the highest and the $\mathrm{W}+$ scenario
Table 1. Effects of climate change on temperature, precipitation and evapotranspiration in the Netherlands for two climate scenarios (Van den Hurk et al., 2006).

\begin{tabular}{lrrrrr}
\hline \multirow{2}{*}{ Variable } & \multicolumn{2}{c}{ Summer $(J J A)$} & & \multicolumn{2}{c}{ Winter (DJF) } \\
\cline { 2 - 3 } \cline { 6 - 6 } & $\mathrm{W}$ & $\mathrm{W}+$ & & $\mathrm{W}$ & $\mathrm{W}+$ \\
\hline mean temperature K & +1.7 & +2.8 & & +1.8 & +2.3 \\
mean $P$ \% & +5.5 & -19.0 & & +7.3 & +14.2 \\
wet day frequency \% & -3.3 & -19.3 & & +0.2 & +1.9 \\
$P$ on wet day \% & +9.1 & +0.3 & & +7.1 & +12.1 \\
reference ET \% & +6.8 & +15.2 & & & \\
\hline
\end{tabular}

has the lowest potential precipitation excess $(P$ minus reference ET) (Table 1). The distinction between the two is the anticipated circulation regime change: a strong change of circulation, which induces warmer and moister winter seasons and increases the likelihood of dry and warm summertime situations (W+), and a weak change of circulation (W).

\subsection{Map compilation}

\subsubsection{General approach}

To detect possible hydrological trends of climate change and their impacts on vegetation types, we overlaid the results of a national hydrological model for two scenarios of climate change with a national vegetation map. Next, we defined decision rules for the sketch map, among others to avoid overinterpretation beyond the uncertainty limits of the hydrological model. These rules were based on a literature survey and expert knowledge of the authors. In two workshops, the resulting sketch map was confronted with the opinion of hydrologists and ecologists from provinces, water boards, and conservation organizations (Van Rooij et al., 2010), which led to minor adjustments. 


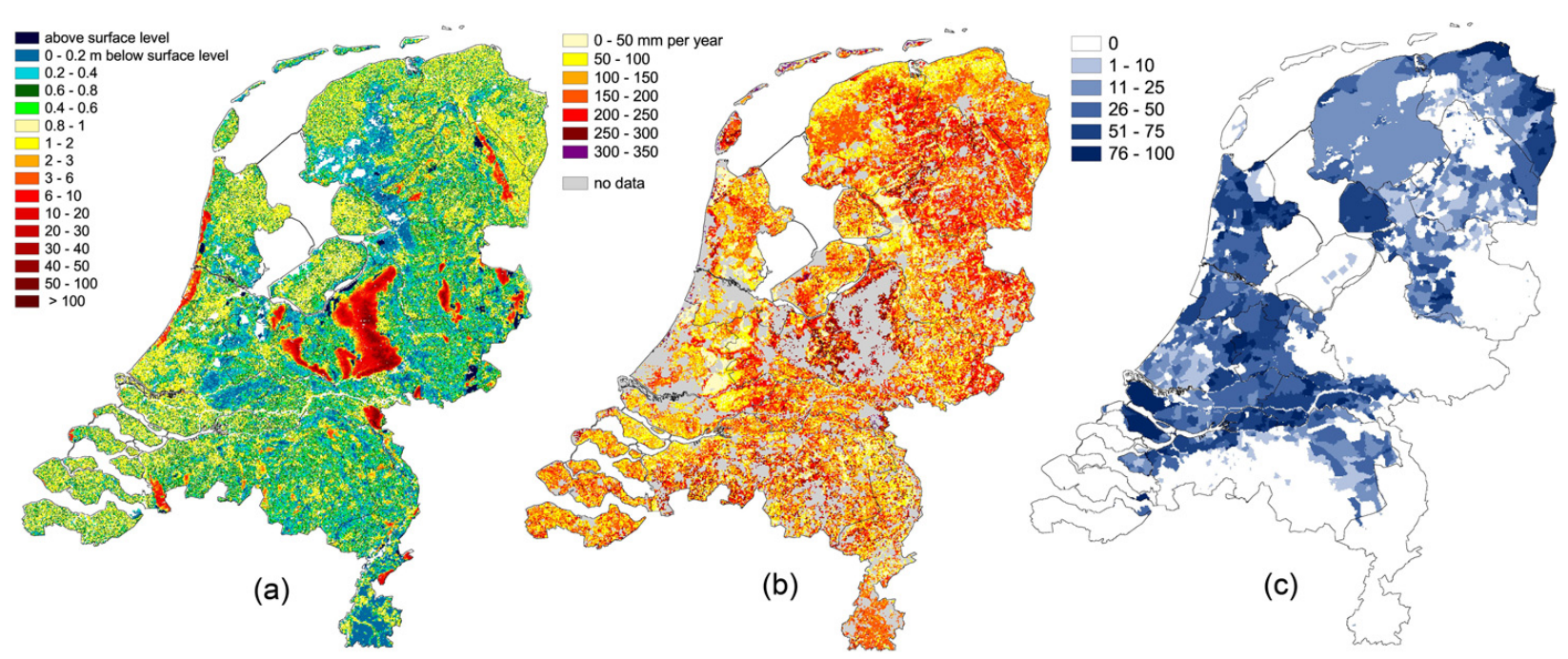

Fig. 2. Examples of hydrological output parameters (Van Beek et al., 2008): (a) average groundwater depth in spring (m - soil surface); (b) soil moisture deficit $T_{\text {red }}\left(\mathrm{mm} \mathrm{yr}^{-1}\right)$; (c) percentage of system alien water (\%), i.e. surface water from the rivers Rhine and Meuse.

\subsubsection{Hydrological simulations combined with a vegetation map}

To identify general trends in possible hydrological effects of climate change, we used the outcomes of simulations applying a national hydrological model (Vermulst and De Lange, 1999). The model had a spatial and temporal resolution of $500 \mathrm{~m}$ and $10 \mathrm{~d}$ (Vermulst and De Lange, 1999), respectively, and was fed with meteorological input data of both the current and the 2050 climate. To obtain feasible computation times, only two meteorological years (with accurate data quality) were considered to represent the current climate: an average (1967) and a dry year (1949), with return periods of 2.5 and $11.7 \mathrm{yr}$, respectively (Beersma et al., 2005). Each calculation for these two characteristic years was preceded with a year to initiate the simulations $(1966,1948)$. For the 2050 climate, we transformed time series of these four years of $P$, reference ET and temperature to the 2050-climate of $\mathrm{W}$ and $\mathrm{W}+$, using transformation software supplied by the KNMI (Bakker and Bessembinder, 2007). This software takes account of shifts in precipitation from summer to winter and of intensified rainfall and drought events. With the aid of a digital elevation model, simulated groundwater levels and seepage intensities were downscaled to a spatial resolution of $25 \times 25 \mathrm{~m}$. Hydrological quantities, relevant for terrestrial ecosystems, considered were moisture deficit (difference between potential and actual transpiration, $T_{\text {red }}$ ), seepage intensity and saline load (all on an annual basis); lowest, highest and spring groundwater depth (relative to soil surface); the average percentage "alien water" in July (Fig. 2). The latter is the surface water from the rivers Rhine and Meuse that is conveyed through smaller streams, canals and ditches through those areas where it is needed to mitigate negative effects of low groundwater levels in agriculture and nature re- serves, and to ensure the stability of dikes and buildings. This water is called "alien" because it has a different chemical composition, which may affect plant species composition.

Based on the work of e.g. Bartholomeus et al. (2008), we assumed that natural vegetation is in equilibrium with, and thus reflects, the prevailing climatic conditions. We overlaid the hydrological output maps for the two scenarios with a national map showing the distribution of 32 vegetation types (defined by Bal et al., 2001) in nature reserves (Fig. 3). In this way we were able to assign current and future frequency distributions of each simulated hydrological quantity to each vegetation type. This analysis confirmed that it is not very sensible to rely blindly on hydrological models: simulated groundwater depths in nature areas for the current climate were on average $45 \mathrm{~cm}$ lower than optimum groundwater levels based on empirical data as given by Runhaar et al. (2002). Nonetheless, we could use the results to identify some general trends about the hydrological consequences of the two climate scenarios, in particular by focussing on the simulated changes in hydrology, instead of on absolute hydrological output variables.

\subsubsection{Basic assumptions to compile the sketch map}

We combined the trends from the hydrological simulations per vegetation type with a literature survey (references in Witte et al., 2009a) and expert knowledge on the involved processes to sketch the consequences of climate change for a limited number of ecosystem types, such as bogs, fens, wet heathlands, dry heathlands, woodlands and streams. The following considerations were used to compile the map: 

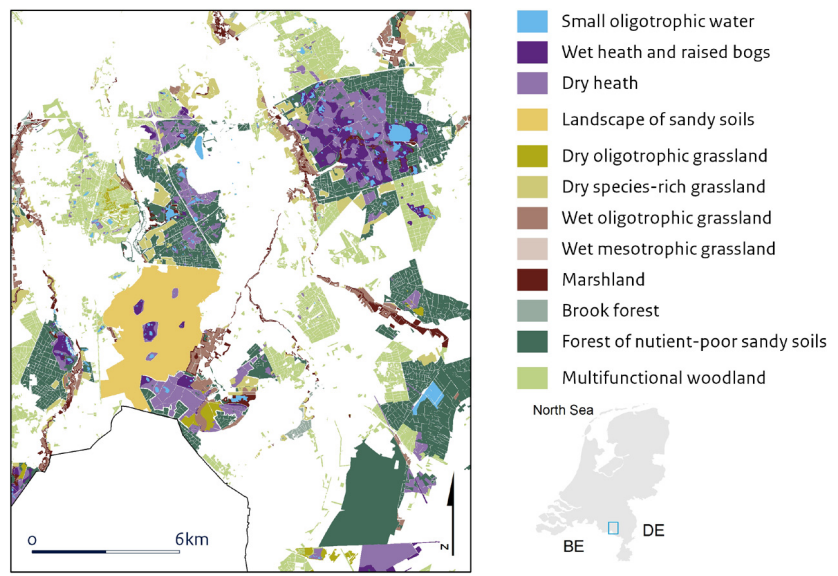

Fig. 3. Part of the of map of national vegetation types according to Bal et al. (2001).

1. We assumed that changes in plant communities as a result of climate change are mainly driven by changes in temperature and water balance components (see, for instance, Bartholomeus et al., 2011a, b; Bazzaz et al., 1996; Kamps et al., 2008; Knapp et al., 2008a; Van Oene and Berendse, 2001; Van Walsum et al., 2001; Witte et al., 2008a). Aggressive invasive species may also play an important role in shaping species communities, but are more strongly related to other human-induced changes than climate change (Tamis et al., 2005).

2. In areas with a deep groundwater level in summer (deeper than one to two meter below rooting zone, depending on the soil texture), water supply to the rooting zone by capillary flow from the groundwater table is negligible (Vervoort and Van der Zee, 2008). In such areas the moisture deficit in summer will increase under both scenarios, due to an increased atmospheric demand (potential ET). The hydrological simulations revealed that the increase is most significant under scenario $\mathrm{W}+$, due to decreased precipitation in summer combined with higher potential ET. Average yearly moisture deficits were predicted to increase from the current $16 \mathrm{~mm} \mathrm{yr}^{-1}$ to 21 and $43 \mathrm{~mm} \mathrm{yr}^{-1}$ under the $\mathrm{W}$ and $\mathrm{W}+$ scenario in an average year, while in a dry year these values are 75,89 and $144 \mathrm{~mm} \mathrm{yr}^{-1}$, respectively.

3. The average groundwater recharge will certainly increase under scenario W. Because of feedbacks of the vegetation to increased summer droughts (closing of stomata, increasing share of bare soil, mosses and lichens), we assume the average recharge on elevated sandy and gravel soils will approximately remain the same or increase somewhat under scenario $\mathrm{W}+$ compared to current conditions. This rule is supported by detailed simulations (Fig. 4) with a coupled soil-water-
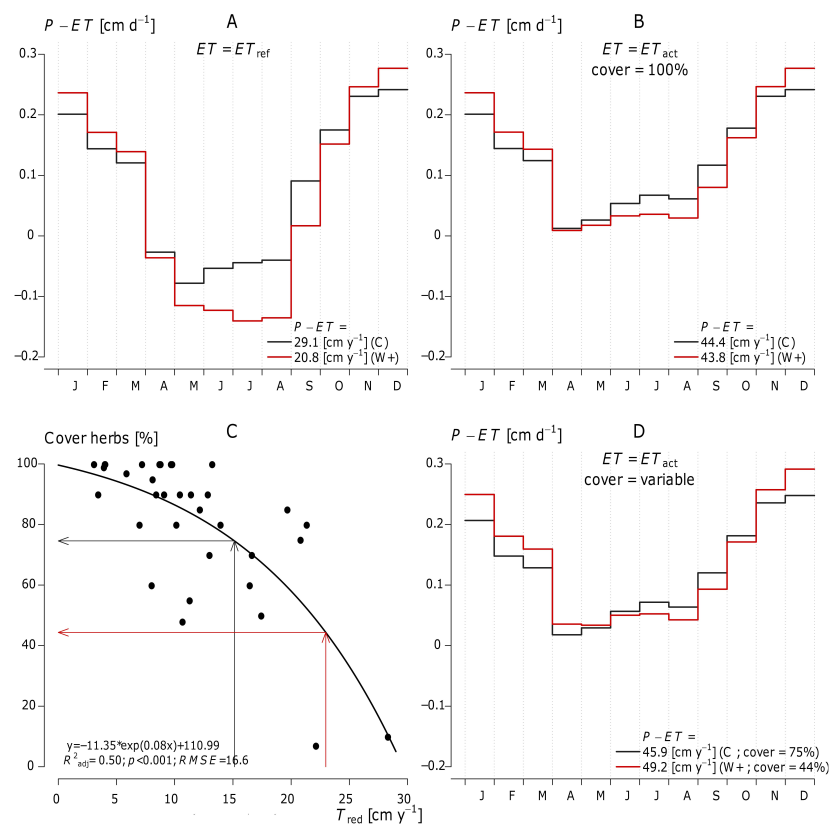

Fig. 4. Monthly averages $P$-ET for the current (C: black lines) and the future (W+ in 2050: red lines), based on 30 year weather data from meteorological station De Bilt (centre of the Netherlands) and simulations of actual ET with the integrated soil-water-atmosphereplant model SWAP (Van Dam et al., 2008) for a groundwaterindependent medium-textured sandy soil: (A) $P$ minus Makkink reference ET; (B) $P$ minus actual ET of a grassland fully covering the ground; (C) empirical relationship between simulated yearly transpiration reduction $T_{\text {red }}$ (defined by Bartholomeus et al., 2011c) versus observed cover fraction of rooting plants, based on 35 plots throughout the Netherlands; (D) $P$ - actual ET of a grassland of which cover of rooting species is adapted to drought according to the relationship in $(\mathbf{C})$.

atmosphere-plant model (Van Dam et al., 2008). Figure 4 shows the yearly course of the actual precipitation excess $(P-$ actual ET) on a medium textured sandy soil with a deep groundwater level, characteristic of elevated sandy soils in the Netherlands, under the current and under the $\mathrm{W}+$ climate. In spite of the fact that the potential precipitation excess $(P$ - reference ET) decreases considerably under scenario $\mathrm{W}+$ (on average from 291 to $208 \mathrm{~mm} \mathrm{yr}^{-1}$, Fig. 4a), the net result of a higher precipitation amount in winter in combination with a stronger reduction of ET in a drier summer is that the annual actual precipitation excess, i.e. the groundwater recharge, remains more or less the same for a soil fully covered by vegetation (Fig. 4b: decrease in groundwater recharge of $6 \mathrm{~mm} \mathrm{yr}^{-1}$ ). However, if we take account of lower vegetation cover at drier soils (empirical relationship in Fig. 4c), groundwater recharge increases a bit under scenario W+ (Fig. $4 \mathrm{~d}$ : increase of $33 \mathrm{~mm} \mathrm{yr}^{-1}$ ). 
4. Since groundwater recharge in recharge areas remains the same or increases lightly under scenario $\mathrm{W}+$ and will certainly increase under scenario $\mathrm{W}$ (see point 3 ), the upward seepage to lower lying discharge areas, such as brook valleys and polders, will on average remain the same or increase as well.

5. In both scenarios, the groundwater level of groundwater-dependent ecosystems in winter and spring is likely to rise slightly: according to the national hydrological simulations, the rise averaged a few $\mathrm{cm}$ over the Netherlands.

6. In groundwater-dependent ecosystems, the groundwater level in summer remains more or less constant under scenario $\mathrm{W}$ and will drop under scenario $\mathrm{W}+$ (according to the transient hydrological model on average $15 \mathrm{~cm}$, but feedbacks not accounted for (see point 1 and 3) may reduce this number).

7. Especially under scenario $\mathrm{W}+$, more river water will be supplied to the low-lying areas of the Netherlands. In areas fed by upward seepage, the amount of inlet water remains unchanged or may even reduce $(\mathrm{W})$.

8. The quality of inlet water in the low part of the Netherlands will deteriorate substantially because of lower river discharges, higher surface water temperatures, and increased upward seepage of (fossil) brackish water in deep polders (Van Vliet and Zwolsman, 2008; Vellinga et al., 2009).

9. The dynamics of the hydrology of the Netherlands will increase: through an intensification of the rainfall showers, wetter winters and drier summers, but also by larger meteorological differences between years (Van den Hurk et al., 2006; Witte et al., 2009a).

\section{Results: the sketch map with accompanying text}

\subsection{Free-draining high part of the Netherlands}

For a proper understanding of the map, we distinguish between the "high part" and the "low part" of the Netherlands. In the sketch map (Fig. 5) the areas dominated by the colours yellow and blue approximately delineate these two regions.

The sketch map reveals that particularly ecosystems in the high part of the Netherlands (Fig. 1b) are vulnerable to climate change. Their vulnerability arises from their dependence on atmospheric precipitation as the only or dominant source of water.

Groundwater-independent vegetation - which is found on glacial ridges, coastal dunes and on hills in the Pleistocene cover-sand landscape - will experience a larger moisture deficit within the growing season. Examples are dry heaths dominated by Calluna vulgaris (heather), and dry dunes dominated by mosses, lichens and xerophilic grasses such as Corynephorus canescens (grey hair-grass). This shortage is particularly expected to increase for scenario $\mathrm{W}+$. As a result, the fraction barren soil in dry heaths and grasslands will increase. It is also expected that the number of plants that flower early and pass dry and hot periods in a dormant condition to reduce metabolic activity (summer sleep) will increase. The increase in barren soil and the accompanying wind erosion will probably be judged positively by nature managers. Currently, these dry ecosystems within the Netherlands experience a lack of dynamics, leading to the dominance of common grasses at the cost of rare species. In dry heathlands, the species diversity potentially increases because of the large number of Ericaceous and Cytisus (broom) species occurring in middle and southern European regions that might invade. The increase in regional species diversity may be hindered, though, by lack of dispersal possibilities.

In dry forests, some species related to a warmer climate are expected to profit from climate change, like Taxus baccata (yew), Ilex aquifolium (ilex hairstreak) and Robinia pseudoacacia (locust tree). Mortality of trees that are more sensitive to drought, like Fagus sylvatica (beech) and Betula pendula (silver birch), may increase when extended drought periods occur more frequently. In addition, dry spells may lead to an increased risk of forest fires.

Also the wet, groundwater-independent, rainwater-fed ecosystems in the elevated parts of the Netherlands are expected to be prone to large hydrological changes. Characteristic vegetation types of raised bogs, nutrient-poor moorland pools and moist and wet heathlands are likely to suffer from drier and warmer summers and the increased hydrological dynamics. Bogs that already suffer from too low groundwater tables will be prone to an increased risk of peat fires, such as occurred in the Netherlands after a very dry spring in 2011. The development of actively peat-accumulating raised bogs may be seriously hampered under the warmer and drier conditions created upon scenario $\mathrm{W}+$. In nutrient-poor moorland pools, higher temperatures will stimulate the break down of organic matter, leading to eutrophication.

Seepage to the lower parts of stream valleys, dune slacks and the edges of large infiltration areas will increase for the scenario $\mathrm{W}$, and presumably for scenario $\mathrm{W}+$ too, although that is highly uncertain because we do not know enough about how vegetation (affecting recharge) in the elevated dry infiltration area will adapt to climate change. The increased upward seepage is beneficial for the biodiversity of natural and dug-spring streams, for species-rich wet dune slacks, and for seepage-dependent ecosystems such as species-rich mesotrophic grasslands (Fig. 1b). However, positive effects under $\mathrm{W}+$ are only expected when the increase in upward seepage is sufficient to compensate for the higher evapotranspiration demand in summer. Whether this is the case depends on the size of the infiltration area, as well as on the future actual ET of the infiltration area (which is, as discussed in the introduction, highly uncertain). Lower 


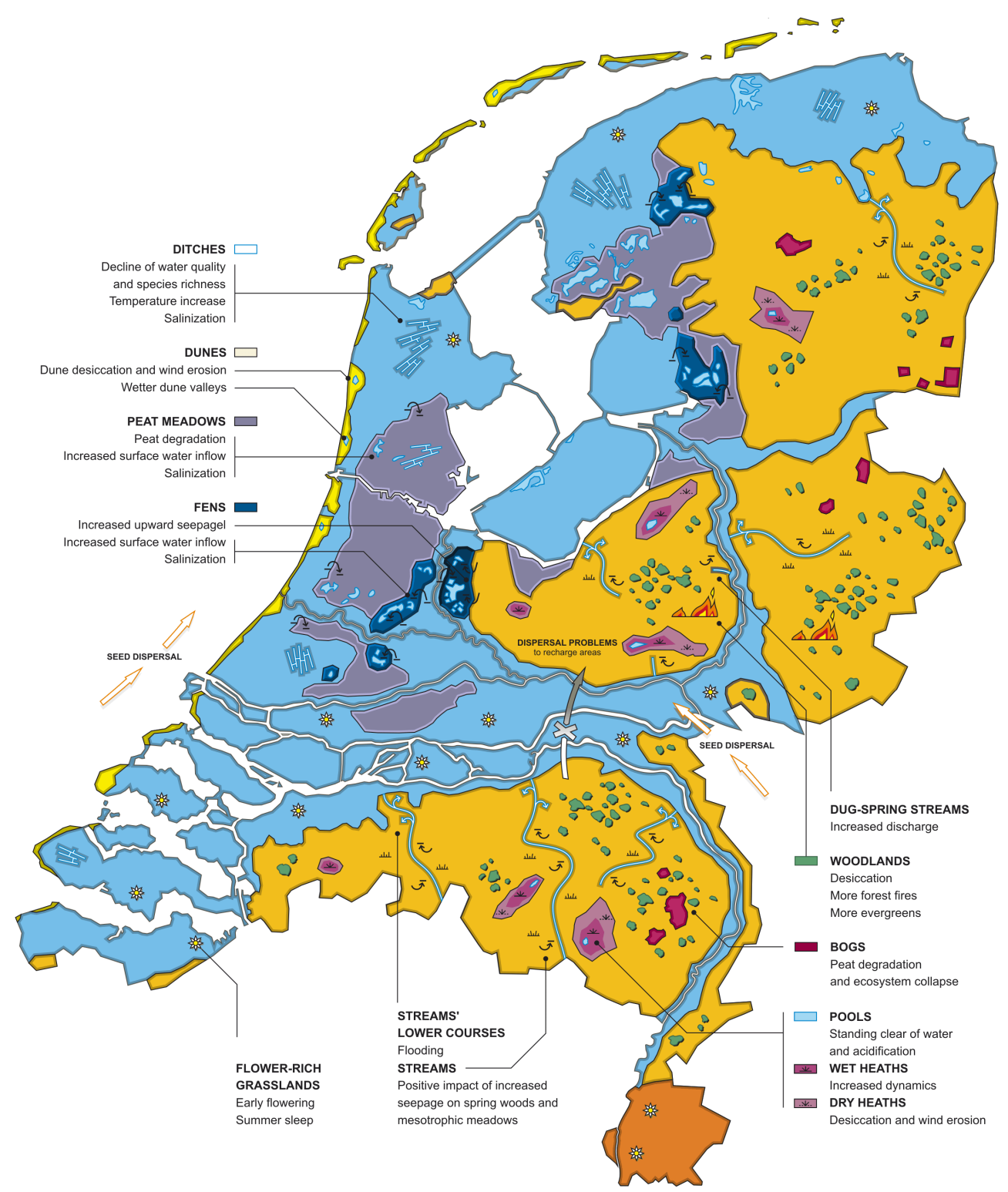

Fig. 5. Ecohydrological sketch map showing the ecohydrological impact of climate change in the Netherlands. Climate change, through its impact on the water cycle, will alter the diversity of plant species and plant communities. These alterations will in turn have an effect on habitat factors that are essential for plant growth such as salt levels, acidity, and the availability of moisture, oxygen and nutrients. The map indicates ecohydrological effects in 2050 under two climate change scenarios: W and $\mathrm{W}+$. Both scenarios include a global temperature rise of $2{ }^{\circ} \mathrm{C}$, increased winter rainfall, drier summers (especially $\mathrm{W}+$ ) and more intensive rainfall events.

reaches of streams will be flooded more frequently, which under the current poor water quality probably is harmful to the vegetation.

\subsection{Artificially drained, lower parts of the Netherlands}

High conservation values in the low part of the Netherlands are especially found in former day mines where peat was excavated as a source of fuel, especially in the 16th and 17th century. After abandoning these cut-over peatlands, peat accumulation started again, particularly as floating vegetation mats (quacking fens). The inset of Figure 1a illustrates the succession of such a floating fen from minerotrophic (colour blue) to ombrotrophic (colour red). In an initial succession stage these mats are often dominated by a vegetation of tall helophytes such as Typha latifolia (bulrush) and several Carex species (sedge sp.); in a next stage a very species-rich vegetation may develop of e.g. Hypnaceae (brown moss sp.) and Sphagnum (peat moss sp.), Phragmites australis (common reed), and a high diversity of forbs, among others orchids; the end of succession may harbour an ombrotrophic 
vegetation of for instance peat moss, Drosera (sundew sp), Eriophorum angustifolium (common cottongrass) and Erica tetralix (cross-leaved heath). The water vegetation is characteristic for nutrient-rich and alkaline conditions, with several Potamogeton and Characeae species (pondweed and stonewort sp.).

Nowadays, these fens are all designated as nature reserve. Most of them are nowadays the higher parts of the landscape, being 1 to $4 \mathrm{~m}$ higher than the surrounding agricultural area, where drainage over the past centuries has caused considerable soil subsidence (Fig. 1a). We expect that these fens, which are characteristic for the Netherlands and harbour many rare and endangered plant and animal species, will suffer from climate change. The higher ET loss in the drier summers will require supply of large amounts of surface water to maintain the high water tables in the fens. With an appropriate water quality, this would not be such a problem, but, as discussed in Sect. 2.4, it is very likely that the quality of inlet water will deteriorate substantially. Possible positive effects of climate change are only foreseen for fens that are fed by upward seepage from adjacent higher sandy areas.

The lower lying fen meadows, which are mostly managed by farmers, will face a loss of biodiversity, not only because of the greater influence of poor quality surface water, but also because a lower groundwater level and a higher temperature in summer will lead to an accelerated decomposition of peat and thus to an increased availability of soil nutrients. Species from mesotrophic conditions are expected to be replaced by fast growing and more common species from nutrient-rich environments. The deterioration of surface water quality will also be a threat to the flora and fauna of ditches and lakes, and the frequency of algal blooms is likely to increase because of the warming.

\section{Discussion}

\subsection{Uncertainties}

Our literature survey and model study identified gaps in our current knowledge, which are needed to better predict the effects of climate change on nature in the Netherlands. To improve the reliability of projections of climate change on the water balance, future research should especially focus on feedbacks of vegetation that impact evapotranspiration and groundwater recharge (Wegehenkel, 2009). Furthermore, for ecological applications we need hydrological models with a higher spatial resolution, i.e. with a resolution that fits both the size and the climate change susceptibility of the ecosystems considered.

Current knowledge about the ecological effects of climate change is also surrounded by large uncertainties. Estimates of ecological impacts are too much based on field observations and on empirical relationships between habitat and vegetation in the current climate, assuming steady state con- ditions (see arguments and references provided in Sect. 1.1). For the benefit of reliable climate projections, future research should focus on processes that directly influence plant performance, i.e. on climate-driven processes that determine the availability of - as well as the plants' needs for - water, oxygen and nutrients in the root environment (Bartholomeus et al., 2011b). Moreover, research is required on the ecological effects of weather extremes (Smith, 2011), as well as on the effects of climate and vegetation on soil development and habitat factors (Douma et al., 2012a; Van Oene et al., 1999).

As a consequence of current shortcomings of hydrological and vegetation models, climate projections with these models should be interpreted with great caution. In this study we therefore combined the results of hydrological simulations, a literature review, process-knowledge and the consultation of experts to draw-up a sketch map that indicatively shows the effects of climate change on a number of ecosystems in the Netherlands.

\subsection{Dissemination of the sketch map in the Dutch society}

We disseminated the sketch map through two technical reports (Van Rooij et al., 2010; Witte et al., 2009a), two publications for a wider public in Dutch professional journals (Witte et al., 2009b, c), and two workshops for provinces, water boards and nature conservation organisations (Van Rooij et al., 2010). The map was soon embraced by others. First, the map appeared in an information brochure of the Dutch provinces (Anonymous, 2009). Then the Netherlands Environmental Assessment Agency (PBL) presented the map in a policy document about adaptation strategies for climateproofing biodiversity (Vonk et al., 2010). In the same year, the "platform communication on climate change" (PCCC), a group of research institutes that aims to communicate with the Dutch society about climate change, issued an information brochure in which the sketch map was discussed (De Coninck et al., 2009). Moreover, the map appeared in a study of climate change effects, published by the largest nature management NGO of the Netherlands, "Vereniging Natuurmonumenten" (Piek et al., 2010). Finally, a version of the map was published in a popular atlas of water in the Netherlands, available in all public book shops (Anonymous, 2010). Apparently, the information provided by our map was timely and needed, which clearly supports the thesis of highly needed methods for establishing a science-policy interface for climate change induced effects on water and ecosystems (Quevauviller, 2011).

The map also led to a question in the Dutch parliament of whether intended measures to combat atmospheric emission of nitrogen around bog reserves could be given up, since the prospects for bog development under the two scenarios are rather pessimistic, particularly under the $\mathrm{W}+$ scenario. This was a tendentious question, fitting to the current trend in some Dutch political parties to immediately use each 
opportunity to question the relevance of nature for society and cut budgets for nature preservation. Although we explicitly warned the users of the sketch map that it is based on climate scenarios, which are still uncertain, this case shows that utmost care should be taken in entering scientific results into societal arenas. Acceptability, credibility and the correct use of modelling results in policy depend on a delicate balance in which user participation and communication between scientists and policy makers are key aspects (Wassen et al., 2011).

Along with our map, we presented information about the increase in precipitation in the Netherlands over the last century: $20 \%$ (Anonymous, 2011). Especially winters became wetter, while the amount of precipitation in summer did not change significantly. In combination with a substantial reduction in the last decades of atmospheric deposition of nitrogen and sulphate, the wetter climate favoured the development of bog vegetation (De Hoop, 2011). Nevertheless, if one of the two scenarios becomes reality, especially the dry W+ scenario, we believe bog ecosystems in the Netherlands will be under serious stress.

\subsection{Adaptive measures}

Given the uncertainties of the future climate and the response of ecosystems, no conclusions can be drawn that may have far-reaching consequences, such as giving up certain nature targets because they would no longer be feasible in the future climate. However, one could at least anticipate possible negative effects of climate change by taking a number of adaptation measures that enhance the robustness of nature reserves. Desiccation of wet heaths and rain-fed moorland pools can be combated by converting highly evaporating dark coniferous woods into less water consuming deciduous forests, grasslands or heathlands. Also damming of gullies, insofar as they are still present from e.g. the former buckwheat fire cultivation, is a way to prevent water loss and stimulate groundwater recharge. External measures are the creation of hydrological buffer zones, increasing surface water levels in agricultural areas, a ban on sprinkling during prolonged drought periods and re-allocation or closing of groundwater abstraction wells. Linking nature areas and enlarging their size makes it easier to maintain high groundwater and surface water levels in relation to the surroundings and increases the supply of upwelling alkaline groundwater into the root zone of plants. In addition, this measure helps species to disperse to locations that offer favourable habitats in the future of ecological networks. The European Natura 2000 network and climate adaptation zones for wetland ecosystems are examples of an adapted spatial planning aimed at linking and enlarging nature areas (Vos et al., 2010).

In nature areas with a controlled water level, such as fens, a more flexible water regime can help to significantly reduce the inlet of surface water of poor quality. The need for inletwater for fens may also be reduced by minimizing downward seepage through a number of external measures: sub- merging adjacent deep polders, closing nearby groundwater abstraction wells and promoting the groundwater recharge in infiltration areas. Submerging adjacent polders may also be a means to create a buffer from which water can be extracted in periods of drought.

In conclusion, climate change should be a stimulus to combat with greater diligence the desiccation of nature and to stimulate the enlargement and implementation of the European Natura 2000 network.

\section{Conclusions}

Current models have serious limitations when used for predicting effects of climate change on natural ecosystems on a regional scale. However, based on the combined result of model simulations, a literature review, process-knowledge and expert judgement, we can qualitatively estimate what ecosystems will probably go through. Given the uncertainty of how climate change will develop, this is sufficient for discussing how to adapt in nature management and spatial planning to expected climatic change.

Climatic change will presumably have the largest influence on natural ecosystems in the high part of the Netherlands that depend on precipitation as the only or major source of water, such as heathlands, dry grasslands, nutrient-poor moorland pools and bogs. Also very susceptible to climate change are fen reserves in the low part of the Netherlands surrounded by deeply drained polders, because such fens depend on the inlet of surface water, of which quality is likely to deteriorate under climate change.

To a certain extent, we can prevent changes in ecosystem functioning and composition, for instance by enlarging and linking nature reserves to combat drought and to facilitate adaptation of species to changed conditions.

We show that the here applied methodology of use of deterministic prediction models, although hampered by limited accuracy, combined with a set of reasonable assumptions is able to bridge the knowledge gap between science and society. However, as scientists we have to be careful how to present results in a political atmosphere where outcomes are easily taken out of their context for short-term political interests.

Acknowledgements. This study was carried out in the framework of both of the Dutch national research program Knowledge for Climate (http://knowledgeforclimate.climateresearchnetherlands.nl/) and the joint research program of the Dutch Water Utility sector (http://www.kwrwater.nl/BTO/). We thank Bob Douma, Lixing Wang, Junguo Liu and an anonymous reviewer for their valuable comments on the manuscript.

Edited by: J. Liu 


\section{References}

Allen, R. G., Pereira, L. S., Smith, M., Raes, D., and Wright, J. L.: FAO-56 Dual crop coefficient method for estimating evaporation from soil and application extensions, J. Irrig. Drain. E.-ASCE, 1, 2-13, 2005.

Anonymous: IPO brochure Klimaateffectatlas: Inspelen op klimaatverandering, IPO, NL, 2009.

Anonymous: De Bosatlas van Nederland Waterland, Noordhoff Uitgevers bv, Groningen, NL, 104 pp., 2010.

Anonymous: De Bosatlas van het klimaat, Noordhoff Uitgevers bv \& KNMI, Groningen, NL, 112 pp., 2011.

Arora, V. K.: Modeling vegetation as a dynamic component in soil-vegetation-atmosphere transfer schemes and hydrological models, Rev. Geophys., 40, 1006, doi:10.1029/2001RG000103, 2002.

Baird, A. J.: Modelling, in: Eco-hydrology, Plants and water in terrestrial and aquatic environments, edited by: Baird, A. J. and Wilby, R. L., Routlegde, London \& New York, 300-345, 1999.

Bakker, A. and Bessembinder, J.: Neerslagreeksen voor de KNMI'06 scenario's, $\mathrm{H}_{2} \mathrm{O}, 22$, 45-47, 2007.

Bal, D., Beije, H. M., Fellinger, M., Haveman, R., van Opstal, A. J. F. M., and Zadelhoff, F. J.: Handboek Natuurdoeltypen, ECLNV, Wageningen, NL, 2001.

Bartholomeus, R. P., Witte, J. P. M., Bodegom, P. M., and Aerts, R.: The need of data harmonization to derive robust empirical relationships between soil conditions and vegetation, J. Veg. Sci., 19, 799-808, 2008.

Bartholomeus, R. P., Witte, J.-P. M., van Bodegom, P. M., van Dam, J. C., and Aerts, R.: Climate change threatens endangered plant species by stronger doi:10.1029/2011jg001693, 2011a.

Bartholomeus, R. P., Witte, J.-P. M., van Bodegom, P. M., van Dam, J. C., de Becker, P., and Aerts, R.: Process-based proxy of oxygen stress surpasses indirect ones in predicting vegetation characteristics, Ecohydrology, in press, doi:10.1002/eco.261, $2011 \mathrm{~b}$.

Bartholomeus, R. P., Witte, J. P. M., and Runhaar, J.: Drought stress and vegetation characteristics on sites with different slopes and orientations, Ecohydrology, in press, doi:10.1002/eco.271, 2011c.

Bastiaanssen, W. G. M., Menenti, M., Feddes, R. A., and Holtslag, A. A. M.: A remote sensing surface energy balance algorithm for land (SEBAL). 1. Formulation, J. Hydrol., 212-213, 198-212, 1998.

Bazzaz, F. A., Bassow, S. L., Berntson, G. M., and Thomas, S. C.: Elevated $\mathrm{CO}_{2}$ and terrestrial vegetation: Implications for and beyond the global carbon budget, in: Global Change and Terrestrial Ecosystems, edited by: Walker, B. and Steffen, W., Cambridge University Press, New York, 43-76, 1996.

Beersma, J. J., Buishand, T. A., and Buiteveld, H.: Droog, droger, droogst. KNMI/RIZA-bijdrage aan de tweede fase van de Droogtestudie Nederland, KNMI, Bilthoven, NL, 2005.

Botkin, D. B., Saxe, H., Araújo, M. B., Betts, R., Bradshaw, R. H. W., Cedhagen, T., Chesson, P., Dawson, T. P., Etterson, J. R., Faith, D. P., Ferrier, S., Guisan, A., Hansen, A., Hilbert, D. W., Loehle, C., Margules, C., New, M., Sobel, M. J., and Stockwell, D. R. B.: Forecasting the effects of global warming on biodiversity, BioScience, 57, 227-236, 2007.

Brolsma, R. J., Van Beek, L. P. H., and Bierkens, M. F. P.: Vegetation competition model for water and light limitation. II: Spatial dynamics of groundwater and vegetation, Ecol. Model., 221,
1348-1363, 2010.

Brooks, P. D., Troch, P. A., Durcik, M., Gallo, E., and Schlegel, M.: Quantifying regional scale ecosystem response to changes in precipitation: Not all rain is created equal, Water Resour. Res., 47, W00J08, doi:10.1029/2010wr009762, 2011.

Dai, A.: Drought under global warming: a review, Climate Change, 2, 45-65, 2011.

De Boer, H. J., Lammertsma, E. I., Wagner-Cremer, F., Dilcher, D. L., Wassen, M. J., and Dekker, D. C.: Climate forcing due to optimization of maximal leaf conductance in subtropical vegetation under rising $\mathrm{CO}_{2}$, Proc. Natl. Acad. Sci., 108, 4041-4046, 2011.

De Coninck, H. C., Van Dorland, R., Dubelaar-Versluis, W., Van de Guchte, C., Jansen, B., Jong, F., Meyer, L., Van de Sandt, K., Seebregts, A. J., and Strengers, B.: De Staat van het Klimaat 2009 - Actueel onderzoek en beleid nader verklaard PCCC, De Bilt \& Wageningen, NL, 2009.

De Hoop, E.: Evaluatie hoogveengebieden in Nederland: evaluatie van het beheer van de hoogvenen van Natuurmonumenten, Staatsbosbeheer, Landschap Overijssel en het Ministerie van Defensie, Natuurmonumenten, 's-Gravenland, NL, 116, 2011.

Douma, J. C.: Putting assembly rules to work: predicting vegetation distribution through plant traits, $\mathrm{PhD}$ thesis, VU Amsterdam University, Amsterdam, 2011.

Douma, J. C., de Haan, M. W. A., Aerts, R., Witte, J. P. M., and van Bodegom, P. M.: Succession-induced trait shifts across a wide range of NW European ecosystems are driven by light and modulated by initial abiotic conditions, J. Ecol., 100, 366-380, doi:10.1111/j.1365-2745.2011.01932.x, 2012a.

Douma, J. C., Witte, J. P. M., Aerts, R., Bartholomeus, R. P., Ordoñez, J. C., Venterink, H. O., Wassen, M. J., and van Bodegom, P. M.: Towards a functional basis for predicting vegetation patterns; incorporating plant traits in habitat distribution models, Ecography, 35, 294-305, 2012b.

Easterling, D. R., Meehl, G. A., Parmesan, C., Changnon, S. A., Karl, T. R., and Mearns, L. O.: Climate extremes: observations, modeling, and impacts, Science, 289, 2068-2074, 2000.

Fay, P. A., Kaufman, D. M., Nippert, J. B., Carlisle, J. D., and Harper, C. W.: Changes in grassland ecosystem function due to extreme rainfall events: implications for responses to climate change, Glob. Change Biol., 14, 1600-1608, 2008.

Feddes, R. A.: Crop factors in relation to Makkink referencecrop evapotranspiration, in: Evaporation and weather, edited by: Hooghart, C., Proceedings and Information. Comm. Hydrological Research TNO, The Hague, 33-47, 1987.

Frei, S., Lischeid, G., and Fleckenstein, J. H.: Effects of microtopography on surface-subsurface exchange and runoff generation in a virtual riparian wetland - A modeling study, Adv. Water Resour., 33, 1388-1401, 2010.

Gerten, D., Schaphoff, S., Haberlandt, U., Lucht, W., and Sitch, S.: Terrestrial vegetation and water balance: hydrological evaluation of a dynamic global vegetation model, J. Hydrol., 286, 249-270, 2004.

Guisan, A. and Thuiller, W.: Predicting species distribution: offering more than simple habitat models, Ecol. Lett., 8, 993-1009, 2005.

Guisan, A. and Zimmermann, N. E.: Predictive habitat distribution models in ecology, Ecol. Model., 135, 147-186, 2000.

Harbaugh, A. W., Banta, E. R., Hill, M. C., and McDonald, M. G.: MODFLOW 2000, The US geological survey modular ground 
water model user guide to modularization concepts and the ground water flow process, US Geological Survey, Reston, Virginia, 2000.

Jackson, R. B., Jobbágy, E. G., and Nosetto, M. D.: Ecohydrology in a human-dominated landscape, Ecohydrology, 2, 383-389, 2009.

Kamps, P., Nienhuis, P., and Witte, J. P. M.: Effects of climate change on the water table in the coastal dunes of the Amsterdam Water Supply, Modflow 2008, 2008,

Karl, T. R., Knight, R. W., and Plummer, N.: Trends in highfrequency climate variability in the twentieth century, Nature, 377, 217-220, 1995.

Knapp, A. K., Beier, C., Briske, D. D., Classen, A. T., Luo, Y., Reichstein, M., Smith, M. D., Smith, S. D., Bell, J. E., Fay, P. A., Heisler, J. L., Leavitt, L. W., Sherry, R., Smith, B., and Weng, E.: Consequences of more extreme precipitation regimes for terrestrial ecosystems, BioScience, 58, 811-821, 2008a.

Knapp, A. K., Beier, C., Briske, D. D., Classen, A. T., Luo, Y., Reichstein, M., Smith, M. D., Smith, S. D., Bell, J. E., Fay, P. A., Heisler, J. L., Leavitt, S. W., Sherry, R., Smith, B., and Weng, E.: Consequences of more extreme precipitation regimes for terrestrial ecosystems, BioScience, 58, 811-821, 2008 b.

Kruijt, B., Witte, J.-P. M., Jacobs, C. M. J., and Kroon, T.: Effects of rising atmospheric $\mathrm{CO}_{2}$ on evapotranspiration and soil moisture: A practical approach for the Netherlands, J. Hydrol., 349, 257267, 2008

Levine, J. M., McEachern, A. K., and Cowan, C.: Rainfall effects on rare annual plants, J. Ecol., 96, 795-806, 2008.

Liu, J.: Consumptive water use in cropland and its partitioning: a high-resolution assessment, Sci. China Ser. E, 52, 3309-3314, 2009.

Liu, J. and Yang, H.: Spatially explicit assessment of global consumptive water uses in cropland: Green and blue water, J. Hydrol., 384, 187-197, 2010.

Makkink, G. F.: Testing the Penman formula by means of lysimeters, Journal of the Institution of Water Engineers, 11, 277-288, 1957.

Moore, G. W. and Heilman, J. L.: Proposed principles governing how vegetation changes affect transpiration, Ecohydrology, 4, 351-358, 2011.

Morin, X. and Lechowicz, M. J.: Contemporary perspectives on the niche that can improve models of species range shifts under climate change, Biology Lett., 4, 573-576, 2008.

Olde Venterink, H. and Wassen, M. J.: A comparison of six models predictiong vegetation response to hydrological habitat change, Ecol. Model., 101, 347-361, 1997.

Pearson, R. G. and Dawson, T. P.: Predicting the impacts of climate change on the distribution of species: are bioclimate envelope models useful?, Global Ecol. Biogeogr., 12, 361-371, 2003.

Piek, H., Biemans, M., and De Hoop, E.: Klimaatverandering en natuurbeheer: verkenning van de effecten van klimaatverandering op het functioneren van de natuur en de mogelijkheden tot het creëren van klimaatrobuuste natuur (adaptatie), Vereniging Natuurmonumenten, 's-Graveland, NL, 2010.

Porporato, A., Laio, F., Ridolfi, L., and Rodriguez-Iturbe, I.: Plants in water-controlled ecosystems: active role in hydrologic processes and response to water stress: III. Vegetation water stress, Adv. Water Resour., 24, 725-744, 2001.

Porporato, A., Daly, E., and Rodriguez-Iturbe, I.: Soil water balance and ecosystem response to climate change, Am. Nat., 164, 625-
632, 2004.

Quevauviller, P.: Adapting to climate change: reducing waterrelated risks in Europe - EU policy and research considerations, Environ. Sci. Policy, 14, 722-729, 2011.

Rodriguez-Iturbe, I. and Porporato, A.: Ecohydrology of WaterControlled Ecosystems: Soil Moisture and Plant Dynamics, Cambridge University Press, Cambridge, 2004.

Runhaar, J., Gehrels, J. C., van der Lee, G., Hennekes, S. M., Wamelink, G. W. W., van der Linden, W., and de Louw, P. G. B.: Waternood deelrapport Doelrealisatie Natuur, STOWA, Utrecht, NL, 2002.

Schaminée, J. H. J., Stortelder, A. H. F., and Westhoff, V.: De Vegetatie van Nederland. Inleiding tot de plantensociologie: grondslagen, methoden en toepassingen, Opulus press, Uppsala/Leiden, 1995.

Schuurmans, J. M., Troch, P. A., Veldhuizen, A. A., Bastiaanssen, W. G. M., and Bierkens, M. F. P.: Assimilation of remotely sensed latent heat flux in a distributed hydrological model, Adv. Water Res., 26, 151-159, 2003.

Smith, M. D.: An ecological perspective on extreme climatic events: a synthetic definition and framework to guide future research, J. Ecol., 99, 656-663, 2011.

Solomon, S., Qin, D., Manning, M., Alley, R. B., Berntsen, T., Bindoff, N. L., Chen, Z., Chidthaisong, A., Gregory, J. M., Hegerl, G. C., Heimann, M., Hewitson, B., Hoskins, B. J., Joos, F., Jouzel, J., Kattsov, V., Lohmann, U., Matsuno, T., Molina, M., Nicholls, N., Overpeck, J., Raga, G., Ramaswamy, V., Ren, J., Rusticucci, M., Somerville, R., Stocker, T. F., Whetton, P., Wood, R. A., and Wratt, D.: Technical Summary, in: Climate Change 2007: The physical science basis. Contribution of working group I to the fourth assessment report of the intergovernmental panel on climate change, edited by: Solomon, S., Qin, D., Manning, M., Chen, Z., Marquis, M., Averyt, K. B., Tignor, M., and Miller, H. L., Cambridge University Press, Cambridge, United Kingdom and New York, NY, USA, 2007.

Sudicky, E. A., Jones, J. P., Park, Y.-J., Brookfield, A. E., and Colautti, D.: Simulating complex flow and transport dynamics in an integrated surface-subsurface modelling framework, Geosci. J., 12, 107-122, 2008.

Tamis, W., Van't Zelfde, M., Van der Meijden, R., and Udo de Haes, H.: Changes in Vascular Plant Biodiversity in the Netherlands in the 20th Century Explained by their Climatic and other Environmental Characteristics, Climatic Change, 72, 37-56, 2005.

Van Beek, E., Haasnoot, M., Meijer, K. M., Delsman, J. R., Snepvangers, J. J. J. C., Baarse, G., Van Ek, R., Prinsen, G. F., Kwadijk, J. C. J., and Van Zetten, J. W.: Verkenning kosteneffectiviteit van grootschalige maatregelen tegen droogteschade als gevolg van de G+ en W+ klimaatscenario's, Deltares, Utrecht (NL), 2008.

Van Bodegom, P. M., Douma, J. C., Witte, J. P. M., Ordoñez, J. C., Bartholomeus, R. P., and Aerts, R.: Going beyond limitations of plant functional types when predicting global ecosystematmosphere fluxes: exploring the merits of traits-based approaches, Glob. Ecol. Biogeogr., 21, 625-636, 2012.

Van Dam, J. C., Groenendijk, P., Hendriks, R. F. A., and Kroes, J. G.: Advances of modeling water flow in variably saturated soils with SWAP, Vadose Zone J., 7, 640-653, 2008.

Van den Hurk, B., Klein Tankink, A., Lenderink, G., Van Ulden, A., Van Oldenborgh, G. J., Katsman, C., Van den Brink, H., Keller, 
F., Bessembinder, J., Burgers, G., Komen, G., Hazeleger, W., and Drijfhout, S.: KNMI Climate change scenarios 2006 for the Netherlands, KNMI, De Bilt, NL, 82 pp., 2006.

Van Oene, H. and Berendse, F.: Predicting responses of ecosystem processes to climate change and nitrogen deposition, in: Longterm effects of climate change on biodiversity and ecosystem processes, edited by: Van Oene, H., Ellis, W. N., Heijmans, M. M. P. D., Mauquoy, D., Tamis, W. L. M., Van Vliet, A. J. H., Berendse, F., Van Geel, B., Van der Meijden, R., and Ulenberg, S. A., Dutch National Research Programme on Global Air Pollution and Climate Change, Bilthoven, NL, 2001.

Van Oene, H., Berendse, F., and De Kovel, C. G. F.: Model analysis of the effects of historic $\mathrm{CO}_{2}$ levels and nitrogen inputs on vegetation succession, Ecol. Appl., 9, 920-935, 1999.

Van Rooij, S., Steingröver, E., Witte, J. P. M., and Goosen, H.: Klimaateffect Atlas 1.0. Klimaatscan Natura 2000 gebieden, Alterra, Wageningen, NL, 2010.

Van Vliet, M. T. H. and Zwolsman, J. J. G.: Impact of summer droughts on the water quality of the Meuse river, J. Hydrol., 353, 1-17, 2008.

Van Walsum, P. E. V., Verdonschot, P. F. M., and Runhaar, J.: Effects of climate and land-use change on lowland stream ecosystems, Dutch National Research Programme on Global Air Pollution and Climate Change, Bilthoven, NL, 2001.

Vellinga, P., Katsman, C. A., Sterl, A., and Beersma, J. J.: Exploring high-end climate change scenarios for flood protection of the Netherlands. International Scientific Assessment carried out at the request of the Delta Committee, KNMI, De Bilt, NL, 2009.

Vermulst, J. A. P. H. and De Lange, W. J.: An analytic-based approach for coupling models for unsaturated and saturated groundwater flow at different scales, J. Hydrol., 226, 262-273, 1999.

Vervoort, R. W. and Van der Zee, S. E. A. T. M.: Simulating the effect of capillary flux on the soil water balance in a stochastic ecohydrological framework, Water Resour. Res., 44, W08425, doi:10.1029/2008wr006889, 2008.

Vonk, M., Vos, C. C., and Van der Hoek, D. J.: Adaptation strategy for climate-proofing biodiversity, 500078005, Netherlands Environmental Assessment Agency (PBL), Den Haag/Bilthoven, NL, 2010.

Vos, C., Van der Hoek, D. C. J., and Vonk, M.: Spatial planning of a climate adaptation zone for wetland ecosystems, Landscape Ecol., 25, 1465-1477, 2010.

Wang, L., Caylor, K. K., Villegas, J. C., Barron-Gafford, G. A., Breshears, D. D., and Huxman, T. E.: Partitioning evapotranspiration across gradients of woody plant cover: Assessment of a stable isotope technique, Geophys. Res. Lett., 37, L09401, doi:10.1029/2010GL043228, 2010.
Wassen, M. J., Runhaar, H., Barendregt, A., and Okruszko, T.: Evaluating the role of participation in modeling studies for environmental planning, Environ. Plann. B, 38, 338-358, 2011.

Wegehenkel, M.: Modeling of vegetation dynamics in hydrological models for the assessment of the effects of climate change on evapotranspiration and groundwater recharge, Adv. Geosci., 21, 109-115, 2009, http://www.adv-geosci.net/21/109/2009/.

Weltzin, J. F., Loik, M. E., Schwinning, S., Williams, D. G., Fay, P. A., Haddad, B. M., Harte, J., Huxman, T. E., Knapp, A. K., Lin, G., Pockman, W. T., Shaw, M. R., Small, E. E., Smith, M. D., Smith, S. D., Tissue, D. T., and Zak, J. C.: Assessing the response of terrestrial ecosystems to potential changes in precipitation, BioScience, 53, 941-952, 2003.

Wigmosta, M. S., Nijssen, B., Storck, P., Singh, V., and Frevert, D.: The Distributed Hydrology Soil Vegetation Model, Other Information: PBD: 1 Apr 2002; Related Information: Mathematical Models of Small Watershed Hydrology and Applications, Medium: X; Size: vp. 7-42 pp., 2002.

Witte, J. P. M., Wójcik, R. B., Torfs, P. J. J. F., De Haan, M. W. H., and Hennekens, S.: Bayesian classification of vegetation types with Gaussian mixture density fitting to indicator values, J. Veg. Sci., 18, 605-612, 2007.

Witte, J. P. M., Bartholomeus, R. P., Cirkel, D. G., and Kamps, P. W. T. J.: Ecohydrologische gevolgen van klimaatverandering voor de kustduinen van Nederland, Kiwa Water Research, Nieuwegein, NLKWR 08.006, 2008a.

Witte, J. P. M., Runhaar, J., and Van Ek, R.: Ecohydrological modelling for managing scarce water resources in a groundwaterdominated temperate system., in: Ecohydrology: Processes, Models and Case Studies, edited by: Harper, D., Zalewski, M., E., J., and Pacini, N., CABI Publishing, Oxfordshire, UK, 88111, 2008b.

Witte, J. P. M., Runhaar, J., and Van Ek, R.: Ecohydrologische effecten van klimaatverandering op de vegetatie van Nederland, KWR Watercycle Research Institute, Nieuwegein, NL, 2009a.

Witte, J. P. M., Runhaar, J., Van Ek, R., and Van der Hoek, D. J.: Eerste landelijke schets van de ecohydrologische effecten van een warmer en grilliger klimaat, $\mathrm{H}_{2} \mathrm{O}, 16 / 17,37-40,2009 \mathrm{~b}$.

Witte, J. P. M., Runhaar, J., Van Ek, R., and Van der Hoek, D. J.: Ecohydrologische effecten van klimaatverandering in kaart gebracht, De Levende Natuur, 110, p. 242, 2009c.

Zhang, K., Kimball, J. S., Nemani, R. R., and Running, S. W.: A continuous satellite-derived global record of land surface evapotranspiration from 1983 to 2006, Water Resour. Res., 46, W09522, doi:10.1029/2009wr008800, 2010. 